\title{
PPBP wt Allele
}

National Cancer Institute

\section{Source}

National Cancer Institute. PPBP wt Allele. NCI Thesaurus. Code C49773.

Human PPBP wild-type allele is located within $4 q 12-q 13$ and is approximately $1 \mathrm{~kb}$ in

length. This allele, which encodes platelet basic protein, plays a role in chemotaxis, neutrophil activation and a variety of other cellular processes. 